\title{
Physicochemical properties and lipid oxidation parameters of selected muscles of Puławska breed fatteners during 14-day ageing in vacuum packaging")
}

\author{
PIOTR DOMARADZKI, PIOTR SKAŁECKI, MICHAŁ PRASOW, \\ MAREK BABICZ*, MARIUSZ FLOREK
}

\begin{abstract}
Institute of Quality Assessment and Processing of Animal Products,
*Institute of Animal Breeding and Biodiversity, Sub-Department of Pig Breeding and Biotechnology Conservation, Faculty of Animal Sciences and Bioeconomy, University of Life Sciences in Lublin, Akademicka 13, 20-950 Lublin, Poland
\end{abstract}

Domaradzki P., Skałecki P., Prasow M., Babicz M., Florek M. Physicochemical properties and lipid oxidation parameters of selected muscles of Puławska breed fatteners during 14-day ageing in vacuum packaging

\section{Summary}

The aim of this study was to determine the influence of the ageing period on the physicochemical properties and lipid quality indicators of pig meat from the native Pulawska breed. The experiment was carried out on samples of skeletal muscles (adjacent part of M. longissimus thoracis and M. longissimus lumborum - LTL, and M. semimembranosus - SM) collected $24 \mathrm{~h}$ after slaughter from 30 carcasses of Pulawska castrated male pigs. Following collection, samples were packaged in vacuum and stored for up to 14 day at a temperature of $4^{\circ} \mathrm{C}$ $\left( \pm 1^{\circ} \mathrm{C}\right)$. The meat $\mathrm{pH}$, colour (CIE $\left.\mathrm{L}^{*} \mathrm{a}^{*} \mathrm{~b}^{*}\right)$, water-holding capacity (drip loss - DL and cooking loss - CL), shear force (WBSF), energy force, and lipid quality indicators (free fatty acids - FFA, peroxide value - PV, and thiobarbituric acid reactive substances expressed as malondialdehyde MDA - TBARS) were measured. A typical course of postmortem glycogenolysis for normal meat was demonstrated. The pH of muscles 45 min after slaughter was 6.55 for LTL and 6.61 for SM, and after $24 \mathrm{~h}$ it was 5.62 and 5.66, respectively. As ageing progressed, the DL of the meat increased significantly (on average 2.4 times), while CL were not significantly changed, being $24.83 \%$ on average. WBSF decreased by approximately $40 \%$ for LTL, and by $18 \%$ for SM. The WBSF value adopted for tender meat $\left(<45 \mathrm{~N} / \mathrm{cm}^{2}\right)$ was obtained on day 14 of the experiment. The progressive oxidative changes in intramuscular fat were not advanced, averaging from $2.06 \%$ for FFA, $0.62 \mathrm{meq} \mathrm{O}_{2} / \mathrm{kg}$ for $\mathrm{PV}$ and $0.24 \mathrm{MDA} / \mathrm{kg}$ for TBARS on day 4 post mortem to $3.71 \%, 1.82 \mathrm{meq} \mathrm{O}_{2} / \mathrm{kg}$ and $0.48 \mathrm{mg} \mathrm{MDA} / \mathrm{kg}$, respectively, on day 14 post mortem. Ageing of pork under vacuum positively influenced the quality characteristics of the meat, with relatively minor oxidative changes. An extended ageing period of up to 14 days can measurably improve the quality characteristics of fresh meat obtained from Pulawska breed pigs, especially for culinary purposes.

Keywords: pigs, Puławska breed, ageing and quality of meat, vacuum packaging

There are currently three native breeds of pigs raised in Poland: Puławska, Złotnicka White and Złotnicka Spotted. Of these, the Puławska breed, associated with the Lublin region, has the longest breeding traditions, dating back to 1926. Although this breed enjoyed popularity for many years because of its favourable performance characteristics, production standards introduced in the late 1980s and early 1990s have limited

1) This research was funded by the National Centre for Research and Development under the strategic programme of scientific research and development works "Natural environment, agriculture and forestry" as part of the BIOSTRATEG project "Directions of use and protection of genetic resources of farm animals under conditions of sustainable development" BIOSTRATEG2/297267/2/NCBR/2016. its use in large-scale livestock farming. This was due to the lower meat content in the carcass compared to the Pietrain, Hampshire or Duroc breeds (1). To prevent the complete elimination of the breed, it was included in a conservation programme in 1997, and is now an important element of livestock biodiversity. Recent years have seen an increased interest in raising pigs of the Puławska breed, which is related to the use of their fresh meat in high-quality regional and traditional products and to their sensory attributes appreciated by consumers (52). In 2018, there were 1611 sows of this breed (46). Similar trends have been reported for pigs of the Spanish native Celta breed, and a recent 
increase in their population is attributed to the activities of breeders' associations and the increased interest of the meat industry in the production of fresh meat and traditional meat products from the fresh meat of this breed (19).

The current population of Puławska pigs is of a transitional use type, between fat-and-meat and meat. One of the goals of the Puławska Breed Genetic Resources Conservation Programme implemented in Poland is to use standardized slaughter traits of this breed (meat content 55.8\%, backfat thickness $12.9 \mathrm{~mm}$, and loin eye height $52.4 \mathrm{~mm}$ ) to produce high quality fresh meat for sale and for sausage-making (46, http://www.bioroznorodnosc.izoo.krakow.pl/system/ files?file=pulawska program ochrony zarzadzenie 12 17 zal.pdf). In addition, the meat of Puławska pigs has high nutritional quality and optimum fat content in terms of sensory attributes, which should be in the range from $2 \%$ to $3 \%(24,55)$. M. longissimus thoracis and $M$. longissimus lumborum contain 71.60-73.99\% of water, $22.00-23.37 \%$ of protein, $2.20-3.70 \%$ of fat and $1.10-1.20 \%$ of ash. The average energy value of the loin of fattening pigs of this breed is $643 \mathrm{~kJ} / 100 \mathrm{~g}$, while the Nutritional Quality Index (NQI) for protein and fat is 5.91 and 0.51 , respectively (42).

The ageing process is a natural phenomenon occurring post mortem in all carcass muscles stored under refrigerated conditions. Many complex processes take place during ageing, and their most important result is an increase in the tenderness of meat and development of a desired flavour and aroma profile (26). Tenderness is one of the most important sensory attributes affecting the palatability of meat, and it is a major factor for consumer acceptance $(10,53)$. In the case of pork, it is generally assumed that, to obtain tender meat, it must be stored at a low temperature for 3 to 7 days. This is a typical period, after which, in accordance with practices followed in the meat industry, fresh pork is distributed to retail outlets and eventually reaches the consumer $(5,14,53)$. Some studies, however, indicate a further increase in pork tenderness on subsequent days post mortem $(13,26,27)$.

In the case of beef, it has been repeatedly demonstrated that meat obtained from native breeds often requires a longer ageing period than meat from cattle of meat breeds or commercial crossbreds $(12,33$, 50). Hypothetically, similar relationships should be expected for pork obtained from native breeds of pigs.

In addition to the unquestionably beneficial effects of post-slaughter ageing of meat, processes take place that may negatively affect its final quality, resulting primarily from the oxidation of muscle tissue components (11). Oxidation of lipids, haem pigments and muscle proteins cause deterioration of the quality, including functional and sensory properties, and nutritional value of both meat and meat products during storage (2).

Given that many studies assess the quality of pork only in the first few days after slaughter (usually up to 7 days), whereas it can be stored under distribution conditions for more than one week, the present study was undertaken to determine the influence of the ageing period (during 14-day vacuum storage) on the physicochemical properties and lipid oxidation indices of meat obtained from pigs of the Puławska breed.

\section{Material and methods}

Animals and sample collection. The experimental material consisted of samples from skeletal muscles, M. semimembranosus (SM) and adjacent $M$. longissimus thoracis and $M$. longissimus lumborum (LTL, section including Th12, Th13, Th14, L1, L2 and L3), collected from 30 carcasses of Puławska fattening pigs. The research was carried out on barrows whose average weight was 120.35 $\pm 8.56 \mathrm{~kg}$. The animals were housed in a litter system, in accordance with welfare requirements (43). Ten pigs were housed in each pen, with an area of $1.2 \mathrm{~m}^{2}$ per animal. The pigs were fed ad libitum dry feed based on wheat and barley with the addition of complementary feedingstuffs. Fattening was conducted in two stages: stage 1 - from 23 to $70 \mathrm{~kg}$ of body weight, where $1 \mathrm{~kg}$ of feed (composition: $50 \%$ wheat, $35 \%$ barley, $15 \%$ complementary feed) contained $157.78 \mathrm{~g}$ of crude protein and 12.94 MJ ME (Metabolizable Energy); stage 2 - from $70 \mathrm{~kg}$ of body weight to day of slaughter, where $1 \mathrm{~kg}$ of feed $(35 \%$ wheat, $55 \%$ barley, $10 \%$ complementary feed) contained $142.35 \mathrm{~g}$ of crude protein and 12.86 MJ ME. After 2 to 4 hours of rest following transport, the animals were slaughtered at meat processing plants in accordance with the EU regulations (7). The pigs were stunned using an automatic system $(230 \mathrm{~V}, 3 \mathrm{~A}, 50 \mathrm{~Hz}$, $700 \mathrm{~W}$ ) and bled in a vertical position. After $24 \mathrm{~h}$ cooling $\left(2^{\circ} \mathrm{C}\right.$, relative humidity $\left.85 \%\right)$, during the cutting of right half-carcasses into primal cuts, muscle samples were taken, divided into 3 sections of equal mass (approx. $500 \mathrm{~g}$ ), and separately vacuum-packed in PA/PE bags with a high gas barrier and a 98\% vacuum level. The samples were stored at $4^{\circ} \mathrm{C} \pm 1{ }^{\circ} \mathrm{C}$ until analysis.

Meat analysis. A $\mathrm{pH}$ meter $\mathrm{CP}-401$ (Elmetron, Poland) with an ERH-12-6 glass combination electrode (HYDROMET, Poland) was used to measure $\mathrm{pH} 45 \mathrm{~min}$, $24 \mathrm{~h}$, and 4, 7 and 14 days after slaughter. Other physicochemical properties were measured on days 4,7 and 14 of ageing in refrigerated storage under vacuum conditions. CIE colour parameters, L* (lightness), $a^{*}$ (red), and $b^{*}$ (yellow) (6), were assessed using a Minolta CR-310 colour saturation meter (illumination/projection $\mathrm{D} 65 / 10^{\circ}$ ) on the exposed surface of the muscle cross-section after $30 \mathrm{~min}$ of blooming under refrigerated conditions $\left(4^{\circ} \mathrm{C} \pm 1^{\circ} \mathrm{C}\right)$.

Drip loss (DL) was determined from the difference in the weight of the sample before and after storage at $4{ }^{\circ} \mathrm{C}$ for an appropriate time. Cooking loss (CL; based on the difference in muscle weight before and after heat treatment) was determined in a water bath. Muscle samples weighing between 100 and $110 \mathrm{~g}$, enclosed in plastic bags, were heated at $70^{\circ} \mathrm{C}$ for $60 \mathrm{~min}$, then cooled under running water for $30 \mathrm{~min}$ and stored at $4^{\circ} \mathrm{C}$ until analysis. Texture parameters were measured using a Zwick/Roell Proline BDO-FB0.5TS single-column testing machine (Zwick $\mathrm{GmbH}$ and $\mathrm{Co}$, Ulm, Germany) in muscle samples used to 
assess cooking loss. A Warner-Bratzler V-blade was used to measure shear force (WBSF, N/ $\mathrm{cm}^{2}$ ) and energy $(\mathrm{J})$ (16). The measurement results were analysed using the TestXpert ${ }^{\circledR}$ II software (Zwick GmbH).

The total intramuscular fat content (IMF, \%) was determined gravimetrically following Soxhlet extraction with n-hexane (41), using a Büchi B-811 extraction system (Büchi Labortechnik AG, Flawil, Switzerland). The content of thiobarbituric acid reactive substances (TBARS) was determined according to Witte et al. (51). The resulting colour was measured at $530 \mathrm{~nm}$ in a Varian Cary 300 Bio spectrophotometer (Varian Australia PTY, Ltd.). TBARS values were calculated by multiplying the absorbance by 5.2 . The results were expressed as $\mathrm{mg}$ of malondialdehyde (MDA) per $1 \mathrm{~kg}$ of meat. The peroxide value (PV - expressed as meq of oxygen $/ \mathrm{kg}$ meat) and the content of free fatty acids (FFA - the percentage of FFA was calculated on the basis of oleic acid) were measured as described by Koniecko (30) with modifications by Joseph et al. (25).

The analyses were performed using the STATISTICA software ver. 13 (TIBCO Inc.). Student's pairwise t-test for independent samples was used to compare the intramuscular fat content of the muscles. The general linear model (GLM) procedure was used for all physicochemical properties, taking into account the muscles tested (LTL and SM), ageing time, and their interactions as fixed effects. Tukey's HSD test was used for comparison of means. Where there was no interaction, one-way ANOVA and the Tukey test were used to estimate the main effect of ageing, separately for LTL and SM. Differences between means at confidence levels of $95 \%$ and $99 \%(\mathrm{p}<0.05$ and $\mathrm{p}<0.01$, respectively) were considered statistically significant.

\section{Results and discussion}

Physicochemical meat quality traits are shown in Figure 1 and Table 1. The results of $\mathrm{pH}$ measurements obtained in the present study indicate normal post mortem glycogenolysis in the muscles tested (typical of meat without defects) (Fig. 1). A decrease in $\mathrm{pH}$ was observed up to day 4 post mortem, followed by a slight increase during subsequent days. No significant differences in $\mathrm{pH}$ values $(\mathrm{P}>0.05)$ were found between muscles during the 14-day ageing period.

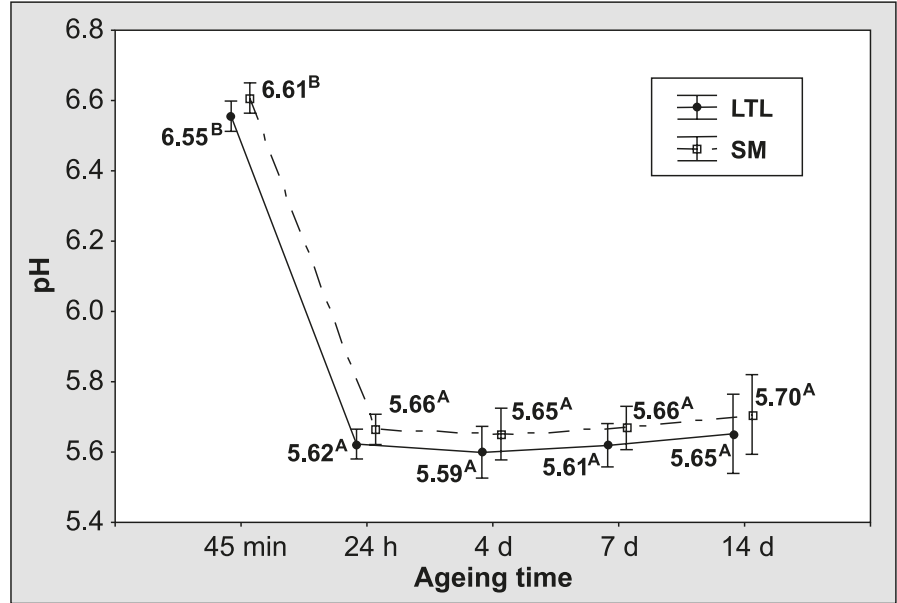

Fig. 1. The pH value of the muscles of Puławska breed fatteners during 14-day ageing $(n=30)$

Explanations: LTL $-M$. longissimus thoracis and $M$. longissimus lumborum; SM - M. semimembranosus; A, B - values with different letters differ significantly at $\mathrm{P}<0.01$

Ageing significantly $(\mathrm{P}<0.01)$ increased the share of red (higher $\mathrm{a}^{*}$ value) and yellow (higher $\mathrm{b}^{*}$ value) in the muscles, and significantly $(\mathrm{P}<0.05)$ increased lightness (higher L* value) in the SM muscle (Tab. 1). $\mathrm{L}^{*}$ and $\mathrm{a}^{*}$ values differed significantly $(\mathrm{P}<0.01)$ between SM and LTL muscles. The LTL muscle of the Puławska pigs showed a significantly higher $\mathrm{L}^{*}$ parameter $(5.40$ units on average; $\mathrm{P}<0.01)$ than the SM muscle, a lower $\mathrm{a}^{*}$ value $(2.91$ units on average; $\mathrm{P}<0.01$ ), and a comparable $\mathrm{b} *$ value (on average 8.22 for LTL and 8.03 for SM; P > 0.05).

In the present study, DL increased significantly $(\mathrm{P}<0.01)$ as ageing progressed. In the case of $\mathrm{CL}$, a downward trend was observed, but the results were not confirmed statistically $(\mathrm{P}>0.05)$. On day 14 of ageing, there was a significant $(\mathrm{P}<0.01)$ decrease in the shear force and energy of the muscles (i.e. improvement in tenderness), on average by $40 \%$ in LTL and by $18 \%$ in SM relative to day 4 .

Indicators of lipid quality are presented in Table 2. The intramuscular fat content was significantly $(\mathrm{P}<0.05)$ higher in LTL than in SM. The SM muscle

Tab. 1. The physicochemical parameters of the muscles of Puławska breed fatteners during 14-day ageing (n $=30, \overline{\mathrm{x}} \pm \mathrm{SD}$ )

\begin{tabular}{|c|c|c|c|c|c|c|c|c|c|c|}
\hline \multirow{2}{*}{\multicolumn{2}{|c|}{ Parameter }} & \multicolumn{3}{|c|}{$\begin{array}{l}\text { M. Iongissimus thoracis } \\
\text { and } M \text {. Iongissimus lumborum (LTL) }\end{array}$} & \multicolumn{3}{|c|}{ M. semimembranosus (SM) } & \multicolumn{3}{|c|}{ Significance level } \\
\hline & & $4 \mathrm{~d}$ & $7 d$ & $14 \mathrm{~d}$ & $4 \mathrm{~d}$ & $7 \mathrm{~d}$ & $14 \mathrm{~d}$ & $\begin{array}{l}\text { Muscle } \\
\text { (M) }\end{array}$ & $\begin{array}{c}\text { Ageing } \\
\text { (A) }\end{array}$ & $M \times A$ \\
\hline \multirow{3}{*}{ CIE } & $L^{*}$ & $54.55 \pm 2.93$ & $55.42 \pm 3.11$ & $55.65 \pm 3.03$ & $47.62^{\mathrm{a}} \pm 5.12$ & $50.36^{\mathrm{ab}} \pm 4.78$ & $51.46^{\mathrm{b}} \pm 3.45$ & $x x$ & $x$ & ND \\
\hline & $a^{*}$ & $18.48^{\mathrm{A}} \pm 1.21$ & $18.94^{\mathrm{AB}} \pm 1.61$ & $20.47^{\mathrm{B}} \pm 1.94$ & $21.62^{A} \pm 1.97$ & $21.07^{A} \pm 1.75$ & $23.92^{\mathrm{B}} \pm 1.59$ & $\mathbf{x x}$ & $x x$ & ND \\
\hline & $\mathbf{b}^{*}$ & $6.54^{A} \pm 1.04$ & $7.87^{\mathrm{B}} \pm 1.46$ & $10.25^{C} \pm 0.99$ & $6.19^{A} \pm 1.42$ & $7.41^{\mathrm{B}} \pm 1.68$ & $10.49^{c} \pm 1.03$ & ND & $x x$ & ND \\
\hline \multicolumn{2}{|c|}{ Drip loss - DL (\%) } & $3.83^{A} \pm 1.50$ & $5.58^{\mathrm{B}} \pm 2.05$ & $8.48^{\mathrm{C}} \pm 2.52$ & $3.02^{\mathrm{A}} \pm 0.71$ & $4.71^{A} \pm 1.66$ & $8.30^{B} \pm 1.97$ & ND & $x x$ & ND \\
\hline \multicolumn{2}{|c|}{ Cooking loss - CL (\%) } & $25.55 \pm 3.16$ & $25.38 \pm 3.80$ & $24.14 \pm 2.76$ & $25.03 \pm 2.20$ & $25.61 \pm 2.72$ & $23.27 \pm 1.69$ & ND & ND & ND \\
\hline \multicolumn{2}{|c|}{ WBSF $\left(\mathrm{N} / \mathrm{cm}^{2}\right)$} & $56.15^{\complement} \pm 21.51$ & $48.77^{\mathrm{bc}} \pm 21.06$ & $33.45^{\mathrm{a}} \pm 12.94$ & $53.30^{\mathrm{bc}} \pm 19.35$ & $50.94^{\mathrm{bc}} \pm 14.13$ & $43.76^{\mathrm{ab}} \pm 11.72$ & ND & $x x$ & $x$ \\
\hline \multicolumn{2}{|c|}{ Shear energy (J) } & $222.09^{\mathrm{bc}} \pm 107.99$ & $192.00^{\mathrm{bc}} \pm 104.16$ & $131.71^{\mathrm{a}} \pm 56.08$ & $245.13^{c} \pm 79.31$ & $217.38^{\mathrm{bc}} \pm 97.20$ & $174.51^{\mathrm{ab}} \pm 58.67$ & $x x$ & $x x$ & $\mathbf{x}$ \\
\hline
\end{tabular}

Explanations: values in rows with different letters $\mathrm{a}, \mathrm{b}$, c differ significantly at $\mathrm{P}<0.05$, and those with letters $\mathrm{A}, \mathrm{B}, \mathrm{C}$ at $\mathrm{P}<0.01$; significance level: $\mathrm{x}, \mathrm{xx}$ at $\mathrm{P}<0.05$ and $\mathrm{P}<0.01$, respectively; $\mathrm{ND}-$ not detected 
Tab. 2. Fat content (IMF) and indicators of lipid quality of the intramuscular fat of the muscles of Pulawska breed fatteners during 14-day ageing $(n=30, \bar{x} \pm S D)$

\begin{tabular}{|c|c|c|c|c|c|c|c|c|c|}
\hline \multirow{2}{*}{ Parameter } & \multicolumn{3}{|c|}{$\begin{array}{l}\text { M. longissimus thoracis } \\
\text { and } M . \text { longissimus lumborum (LTL) }\end{array}$} & \multicolumn{3}{|c|}{ M. semimembranosus (SM) } & \multicolumn{3}{|c|}{ Significance level } \\
\hline & $4 \mathrm{~d}$ & $7 \mathrm{~d}$ & $14 \mathrm{~d}$ & $4 d$ & $7 \mathrm{~d}$ & $14 \mathrm{~d}$ & $\begin{array}{c}\text { Muscle } \\
\text { (M) }\end{array}$ & $\begin{array}{c}\text { Ageing } \\
\text { (A) }\end{array}$ & $M \times A$ \\
\hline IMF (\%) & $2.57^{\mathrm{b}} \pm 0.81$ & - & - & $1.98^{\mathrm{a}} \pm 0.71$ & - & - & $x$ & ND & ND \\
\hline FFA (\%) & $1.45^{A} \pm 0.27$ & $2.24^{A B} \pm 0.93$ & $4.26^{c} \pm 0.58$ & $2.67^{B} \pm 1.17$ & $2.98^{\mathrm{B}} \pm 0.52$ & $3.15^{\mathrm{B}} \pm 0.60$ & ND & $x x$ & $x \mathbf{x}$ \\
\hline PV (meq $0_{2} / \mathbf{k g}$ meat) & $0.71^{A} \pm 0.26$ & $0.89^{A B} \pm 0.25$ & $2.05^{0} \pm 0.41$ & $0.52^{A} \pm 0.30$ & $1.20^{\mathrm{BC}} \pm 0.23$ & $1.58^{\mathrm{C}} \pm 0.22$ & ND & $x x$ & $x x$ \\
\hline TBARS (mg MDA/kg meat) & $0.20^{A} \pm 0.05$ & $0.32^{\mathrm{B}} \pm 0.03$ & $0.47^{\mathrm{CD}} \pm 0.03$ & $0.27^{\mathrm{B}} \pm 0.04$ & $0.42^{\mathrm{c}} \pm 0.05$ & $0.49^{\circ} \pm 0.04$ & $x x$ & $x x$ & $x x$ \\
\hline
\end{tabular}

Explanations: IMF - intramuscular fat; FFA - free fatty acids; PV - peroxide value; TBARS - thiobarbituric acid reactive substances; values in rows with different letters a, b, c differ significantly at $\mathrm{P}<0.05$, and those with letters $\mathrm{A}, \mathrm{B}, \mathrm{C}$ at $\mathrm{P}<0.01$; significance level: $\mathrm{x}$, $\mathrm{xx}$ for $\mathrm{P}<0.05$ and $\mathrm{P}<0.01$, respectively; $\mathrm{ND}$ - not detected

had a significantly $(\mathrm{P}<0.01)$ higher TBARS value (by $0.06 \mathrm{mg} \mathrm{MDA} / \mathrm{kg}$ on average) than the LTL muscle. No significant differences $(\mathrm{P}>0.05)$ were found for FFA and PV values. From day 4 to day 14 of refrigerated storage of the muscles, progressive $(\mathrm{P}<0.01)$ oxidative and hydrolytic changes in the lipids were observed, as evidenced by the increase in FFA, PV and TBARS values.

One of the most important parameters used in monitoring changes in muscle tissue after slaughter is the $\mathrm{pH}$ value, which makes it possible to diagnose quality defects in fresh meat. In addition, $\mathrm{pH}$ is one of the main indicators of the sensory quality of meat. An appropriate $\mathrm{pH}$ of meat after slaughter ensures proper water retention, an attractive colour, tenderness and palatability (22). It is believed that in order to ensure high sensory quality, the $\mathrm{pH}$ of fresh meat for sale should range from 5.50 to 5.80 after $24 \mathrm{~h}$ and $48 \mathrm{~h}$ (21). This range of meat $\mathrm{pH}$ was found in the present study until day 14 post mortem. Similar relationships were also reported by Wojtysiak and Połtowicz (53) and Juárez et al. (27) for pork aged for 7 and 14 days, respectively.

The meat of pigs of local breeds generally has a slower rate of decline in post mortem $\mathrm{pH}$ and thus higher ultimate $\mathrm{pH}$ values compared to the meat of commercial breeds. This is probably linked to the more oxidative muscle metabolism of pigs of local breeds (higher proportion of type I fibres) $(8,18,19$, $52)$. In addition, muscles with a higher intramuscular fat content show a slower decline in $\mathrm{pH}$ after slaughter (8). A lower ultimate $\mathrm{pH}$ of meat was associated with increased lightness, greater drip loss, and poorer tenderness and palatability (22). Similar relationships were also reported between ultimate $\mathrm{pH}$ and $\mathrm{DL}$ and CL (44).

In the present study, $\mathrm{pH}$ values for LTL were lower than those for SM. This was most probably due to differences in the muscle fibre composition of the two muscles (53). Similar differences between muscles of Puławska pigs have been reported earlier (34). Renaudeau and Mourot (44) also showed that $\mathrm{pH}_{24}$ was lower in the LTL of Creole pigs than it was in their SM (5.71 vs. 5.88).
A lighter and more saturated colour (i.e. an increase in parameters $\mathrm{L}^{*}, \mathrm{a}^{*}$ and $\mathrm{b}^{*}$ ) is quite commonly observed and is well documented in vacuum aged beef $(11,37,38)$. In the case of pork, this is not so obvious, possibly because of the small number of studies on this subject. Juárez et al. $(26,27)$ observed an increase in colour coordinates for up to 14 days post mortem. Tikk et al. (49) reported slightly more complex relationships, with a lack of clear trends during a 15-day pork ageing period. Moreover, these authors reported a lighter colour of the longissimus thoracis muscle, a lower share of red and similar yellow in comparison to SM. Similar observations were made in the present study for muscles of the Puławska pigs.

Lindahl et al. (32) report an increase in colour parameters only in the initial post mortem period, but they note that ageing increases the capacity of vacuum-packaged pork to bloom. The increase in meat lightness during ageing is generally ascribed to protein degradation (directly dependent on ultimate $\mathrm{pH}$ ), which results in increased light dispersion (3). In addition, the level of oxygen on the meat surface, as well as the rate of its diffusion on the meat surface, increases during ageing because of the continuous inactivation of oxygen-consuming enzymes (39). These relationships are confirmed by the increase in oxymyoglobin concentration and a lower myoglobin level observed during ageing $(31,32)$.

One of the advantages of the meat of native pig breeds (apart from a higher IMF content) may be its darker colour $(8,52)$, which is thought to be preferred by consumers (36). The darker and redder colour of the meat of native pigs compared to that of commercial breeds is related not only to the higher $\mathrm{pH}$ of the meat and the usually older age of native pigs at slaughter, but also to the higher content of myoglobin, due to a high proportion of oxidative muscle fibres $(8,19,52)$.

Although the colour parameters observed in the present study should be considered relatively high (especially for the LTL muscle), these results are consistent with literature data, as in some local breeds, such as Iberíco, Krškopoljski, Mangulica, Nero Siciliano, and Casertana, both dark $\left(\mathrm{L}^{*}<46\right)$ and light $\left(\mathrm{L}^{*}>52\right)$ meat is observed (8). Moreover, the colour of the meat of 
Puławska pigs in the CIE L*a*b* colour space in the present study was similar to results reported earlier, which ranged from 47.16 to 53.17 for $L^{*}$, from 6.95 to 16.99 for $\mathrm{a}^{*}$, and from 2.02 to 7.22 for $\mathrm{b}^{*}(21,29$, 34, 52).

Water-holding capacity (WHC) is one of the most important factors for the economic value and quality of meat. Exudative meat (with high drip loss) is a serious problem in commercial pig breeds, whose muscles contain more type II muscle fibres. In contrast, quality defects such as PSE occur only sporadically or not at all in meat obtained from pigs of native breeds $(20$, 28). DL and CL are among the most commonly used indicators for determining WHC (19). In our research, ageing time significantly influenced drip loss, but cooking loss was comparable. Our results are similar to those reported for meat of Puławska pigs by other authors $(9,21,29,34)$ for DL (from $2.05 \%$ to $4.70 \%$ ) and for CL (from $24.88 \%$ to $27.46 \%$ ). It should be noted, however, that these parameters were determined only in the initial post mortem period, i.e. from day 1 to day 3 .

Wojtysiak and Połtowicz (52) and Florowski et al. (17) report that the meat of Puławska pigs has a significantly lower drip loss (by $1.93 \%$ and $1.40 \%$, respectively) and cooking loss (by $2.17 \%$ and $3.8 \%$, respectively) than that of Polish improved white pigs. Other studies also show a lower drip loss and lower cooking loss for the meat of local pigs compared to that of commercial breeds $(18,39,44)$. This indicates that the meat of native pig breeds has a high water-binding capacity and is more suitable for processing (52).

Post mortem ageing significantly improves meat tenderness of improved pigs $(13,26,27,53)$. According to some researchers, meat from local pigs is tougher than that of improved pigs, which appears to be linked to their older age and increased collagen content and crosslinking (18, 19). Furthermore, muscles with a higher proportion of slow-twitch oxidative fibres (type I) have higher shear force values (53).

Iwańska et al. (23) adopted the following WBSF ranges for pork: $<30 \mathrm{~N} / \mathrm{cm}^{2}-$ very tender, $30-45 \mathrm{~N} / \mathrm{cm}^{2}$ - tender, $60-90 \mathrm{~N} / \mathrm{cm}^{2}$ - tough, and $>90 \mathrm{~N} / \mathrm{cm}^{2}-$ very tough. Thus it should be noted that in the present study the WBSF level for very tender meat was not achieved until day 14 post mortem. According to Channon et al. (5) and Wood et al. (54), ageing of pork for 7 days and 10 days, respectively, has a greater impact on the organoleptic properties of fresh meat (especially tenderness) than does the genotype of pigs (Duroc vs. Large White vs. Duroc $\times$ Large White).

Earlier studies have indicated that as the post mortem ageing of meat progresses, PV, TBARS and FFA increase $(15,35,40,45,48)$. Similar and significant relationships were found in the present study. Park et al. (40) observed an increase in FFA from $4.40 \%$ to $7.90 \%$, in PV from 2.5 meq $\mathrm{O}_{2} / \mathrm{kg}$ to $12.1 \mathrm{meq} \mathrm{O}_{2} / \mathrm{kg}$, and in TBARS from $0.15 \mathrm{mg} \mathrm{MDA} / \mathrm{kg}$ to $0.23 \mathrm{mg}$
MDA $/ \mathrm{kg}$ in the LTL of Duroc $\times$ Yorkshire $\times$ Landrace crossbreds during 28-day refrigerated storage.

During extended ageing, pork can suffer excessive moisture losses and high oxidative rancidity due to its high levels of polyunsaturated fatty acids (26). Lipid oxidation in meat is one of the main causes of deterioration in its quality, as it leads to changes in its nutritional value and sensory properties. Measurement of the peroxide value $(\mathrm{PV})$ is the most common method to determine the content of hydroperoxides (the primary products of lipid oxidation) formed during the initial stages of the oxidation cascade, while the TBARS test is widely used to assess secondary oxidation products reacting with thiobarbituric acid (mainly malondialdehyde-MDA) $(4,48)$. In addition, lipolysis is believed to promote lipid oxidation because of the accumulation of free fatty acids (FFA) susceptible to peroxidation, particularly long-chain unsaturated FFA (35). In meat science, the oxidative stability of lipids is most often determined on the basis of TBARS values alone, and primary lipid oxidation products are rarely considered.

Despite the changes observed, the indicators of the degree of lipid rancidity (TBARS, PV and FFA) were relatively low, which confirms the good oxidative stability of the meat and the protective role of vacuum packing. The threshold TBARS values beyond which off-flavours in pork can be detected have been reported to be 0.5 to $1.0 \mathrm{mg} / \mathrm{kg}$ of meat (47), which indicates that the TBARS values observed in our study are not relevant from the sensory perspective.

The results indicate that the ageing of fresh meat obtained from pigs of the Puławska breed under refrigerated conditions for 14 days had a positive effect on the visual attractiveness (colour) of the meat as well as on its tenderness. The progressive oxidative changes in intramuscular fat were relatively minor, which indicates that the meat had a good oxidative stability and was suitable for ageing under vacuum conditions. Although the ageing of pork for 14 days may seem difficult to accept from the perspective of distribution practices, it is worth considering a longer time than that currently used for pork (usually not exceeding 7 days). Longer ageing may be of particular importance and may have measurable benefits for trade in fresh meat of Puławska pigs.

\section{References}

1. Babicz M., Skatecki P., Domaradzki P., Litwińczuk A., Hałabis M., Prasow M., Łukasik M., Kaliniak A.: The slaughter value of fatteners of Pulawska breed depending on the slaughter weight. J. Anim. Sci. Biol. Bioecon. 2018, 36, 9-20.

2. Bekhit A. E. D. A., Hopkins D. L., Fahri F. T., Ponnampalam E. N.: Oxidative processes in muscle systems and fresh meat: Sources, markers, and remedies. Compr. Rev. Food Sci. 2013, 12, 565-597.

3. Beriain M. J., Goñi M. V., Indurain G., Sarriés M. V., Insausti K.: Predicting Longissimus dorsi myoglobin oxidation in aged beef based on early post-mortem colour measurements on the carcass as a colour stability index. Meat Sci. 2009, 81, 439-445.

4. Botsoglou E., Govaris A., Ambrosiadis I., Fletouris D., Botsoglou N.: Effect of olive leaf (Olea europea L.) extracts on protein and lipid oxidation of long-term frozen n-3 fatty acids-enriched pork patties. Meat Sci. 2014, 98, 150-157. 
5. Channon H. A., Kerr M. G., Walker P. J.: Effect of Duroc content, sex and ageing period on meat and eating quality attributes of pork loin. Meat Sci. 2004, 66, 881-888

6. CIE: Colorimetry. $3^{\text {rd }}$ ed. Commission International de l'Eclairage, Vienna 2004, p. 16-20.

7. Council Regulation (EC) No $1099 / 2009$ of 24 September 2009 on the protection of animals at the time of killing. OJ L303, 18.11.2009, p. 1-30.

8. Čandek-Potokar M., Lukač N. B., Tomažin U., Škrlep M., Nieto R.: Analytical Review of Productive Performance of Local Pig Breeds, [in:] Čandek-Potokar M. (ed.): European local pig breeds - diversity and performance. A study of project TREASURE, IntechOpen, London 2019, p. 1-23.

9. Debrecéni O., Lipová P., Bučko O., Cebulska A., Kapelański W.: Effect of pig genotypes from Slovak and Polish breeds on meat quality. Arch. Anim. Breed. 2018, 61, 99-107.

10. Destefanis G., Brugiapaglia A., Barge M. T., Dal Molin E.: Relationship between beef consumer tenderness perception and Warner-Bratzler shear force. Meat Sci. 2008, 78, 153-156.

11. Domaradzki P., Litwińczuk Z., Florek M., Litwińczuk A.: Changes in physicochemical and sensory properties of beef meat depending on its ageing conditions. Żywn. Nauk. Technol. Ja. 2016, 106, 35-53.

12. Domaradzki P., Litwińczuk Z., Florek M., Żólkiewski P.: Effect of ageing on the physicochemical properties of musculus longissimus lumborum of young bulls of five breeds. Med. Weter. 2017, 73, 802-810.

13. Ellis M., Brewer M. S., Sutton D. S., Lan H. Y., Johnson R. C., McKeith F. K Aging and cooking effects on sensory traits of pork from pigs of different breed lines. J. Muscle Foods 1998, 9, 281-291.

14. Feldhusen F., Kuhne M.: Effects of ultrarapid chilling and ageing on length of sarcomeres and tenderness of pork. Meat Sci. 1992, 32, 161-171.

15. Fernando L. N., Berg E. P., Grün I. U.: Quantitation of hexanal by automated SPME for studying dietary influences on the oxidation of pork. J. Food Compos. Anal. 2003, 16, 179-188.

16. Florek M., Junkuszew A., Bojar W., Skałecki P., Greguła-Kania M., LitwińczukA., Gruszecki T. M.: Effect of vacuum ageing on instrumental and sensory textural properties of meat from Uhruska lambs. Ann. Anim. Sci. 2016, 16, 601-609.

17. Florowski T., Pisula A., Adamczak L., Buczyński J. T., Orzechowska B. Technological parameters of meat in pigs of two Polish local breeds - Zlotnicka Spotted and Pulawska. Anim. Sci. Pap. Rep. 2006, 24, 217-224.

18. Franci O., Bozzi R., Pugliese C., Acciaioli A., Campodoni G., Gandini G. Performance of Cinta Senese pigs and their crosses with Large White. 1 Muscle and subcutaneous fat characteristics. Meat Sci. 2005, 69, 545-550.

19. Franco D., Vazquez J. A., Lorenzo J. M.: Growth performance, carcass and meat quality of the Celta pig crossbred with Duroc and Landrance genotypes. Meat Sci. 2014, 96, 195-202.

20. Grześkowiak E., Borys A., Borzuta K., Buczyński J. T., Lisiak D.: Slaughter value, meat quality and back fat fatty acid profile in Zlotnicka Spotted fatteners. Anim. Sci. Pap. Rep. 2009, 27, 115-125.

21. Grześkowiak E., Borzuta K., Strzelecki J., Lisiak D.: Results of assessment of meat quality in fat-meat type pigs currently fattened on small farms. Anim. Sci. Pap. Rep. 2006, 24, 113-118.

22. Huff-Lonergan E., Baas T. J., Malek M., Dekkers J. C. M., Prusa K., Rothschild M. F.: Correlations among selected pork quality traits. J. Anim. Sci. 2002, 80, 617-627

23. Iwańska E., Mikołajczak B., Grześ B., Pospiech E.: Impact of post mortem aging of pork on changes in the isoelectric point of the proteins and tenderness. Med. Weter. 2016, 72, 458-462.

24. Jaworska D., Przybylski $W$ : The effect of selected factors on sensory quality of pork. Żywn. Nauk. Technol. Ja. 2014, 96, 21-35.

25. Joseph S., Chatli M. K., Biswas A. K., Sahoo J.: Oxidative stability of pork emulsion containing tomato products and pink guava pulp during refrigerated aerobic storage. J. Food Sci. Technol. 2014, 51, 3208-3216.

26. Juárez M., Caine W. R., Dugan M. E. R., Hidiroglou N., Larsen I. L., Uttaro B. Aalhaus $J$. L.: Effects of dry-ageing on pork quality characteristics in different genotypes. Meat Sci. 2011, 88, 117-121.

27. Juárez M., Clemente I., Polvillo O., Molina A.: Meat quality of tenderloin from Iberian pigs as affected by breed strain and crossbreeding. Meat Sci. 2009, 81, 573-579.

28. Kapelański W., Buczyński J. T., Bocian M.: Slaughter value and meat quality in the Polish native Złotnicka Spotted pig. Anim. Sci. Pap. Rep. 2006, 24, 7-13.

29. Kasprzyk A., Babicz M., Kamyk-Kamieński P., Lechowski J.: Slaughter value and meat quality of Pulawska and Polish Landrace breeds fatteners. Ann. UMCS, sec EE Zoot. 2013, 31, 1-9.

30. Koniecko R.: Handbook for meat chemists. Avery Publishing Group Inc., Wayne, New Jersey 1979, p. 53-55.

31. Lindahl G., Enfält A. C., Andersen H. J., Lundström K.: Impact of RN genotype and ageing time on colour characteristics of the pork muscles longissimus dorsi and semimembranosus. Meat Sci. 2006, 74, 746-755.
32. Lindahl G., Karlsson A. H., Lundström K., Andersen H. J.: Significance of storage time on degree of blooming and colour stability of pork loin from different crossbreeds. Meat Sci. 2006, 72, 603-612

33. Marino R., Albenzio M., Caroprese M., Napolitano F., Santillo A., Braghieri A. Effect of grazing and dietary protein on eating quality of Podolian beef. J. Anim. Sci. 2011, 89, 3752-3758.

34. Milczarek A., Osek M.: Meat quality of Pulawska breed pigs fed mixtures with low-tannin faba bean meal. Żywn. Nauk. Technol. Ja. 2016, 104, 57-67.

35. Morcuende D., Estévez M., Ruiz J., Cava R.: Oxidative and lipolytic deterioration of different muscles from free-range reared Iberian pigs under refrigerated storage. Meat Sci. 2003, 65, 1157-1164

36. Newcom D. W., Stadler K. J., Bass T. J., Godwin R. N., Parrish F. C., Wiegand $B$. $R$.: Breed differences and genetic parameters of myoglobin concentration in porcine longissimus muscle. J. Anim. Sci. 2004, 82, 2264-2268.

37. Oliete B., Carballo J. A., Varela A., Moreno T., Monserrat L., Sanchez L.: Effect of weaning status and storage time under vacuum upon physical characteristics of meat of the Rubia Gallega breed. Meat Sci. 2006, 73, 102-108.

38. Oliete B., Moreno T., Carballo J. A., Varela A., Monserrat L., Sánchez L. Influence of ageing time on the quality of yearling calf meat under vacuum. Eur. Food Res. Technol. 2005, 220, 489-493.

39. Park B. Y., Kim N. K., Lee C. S., Hwang I. H.: Effect of fibre type on post-mortem proteolysis in longissimus muscle of Landrace and Korean native black pigs. Meat Sci. 2007, 77, 482-491.

40. Park S. Y., Kim Y. J., Lee H. C., Yoo S. S., Shim J. H., Chin K. B.: Effects of pork meat cut and packaging type on lipid oxidation and oxidative products during refrigerated storage $\left(8^{\circ} \mathrm{C}\right)$. J. Food Sci. 2008 , 73, C127-C134.

41. PN-ISO 1444. Meat and meat products - Determination of free fat content. The Polish Committee for Standardization, Warsaw 2000.

42. Prasow M., Babicz M., Domaradzki P., Skałecki P., Litwińczuk A., Kaliniak A.: Slaughter value and quality of meat of Polish local breed pigs. J. Anim. Sci. Biol. Bioecon. 2018, 36, 5-17.

43. Regulation of the Minister of Agriculture and Rural Development of 15 February 2010 on the requirements and procedure for maintaining farm animal species for which protection standards have been laid down in European Union regulations. Warsaw, Poland: Journal of Laws 2010, no. 56, item 344, as amended.

44. Renaudeau D., Mourot J.: A comparison of carcass and meat quality characteristics of Creole and Large White pigs slaughtered at $90 \mathrm{~kg}$ BW. Meat Sci. 2007, $76,165-171$

45. Sierra V., Guerrero L., Fernández-Suárez V., Martínez A., Castro P., Osoro K. Rodríguez-Colunga M. J., Coto-Montes A., Oliván M.: Eating quality of beef from biotypes included in the PGI "Ternera Asturiana" showing distinct physicochemical characteristics and tenderization pattern. Meat Sci. 2010, 86, 343-351.

46. Szyndler-Nędza M., Luciński P., SkrzypczakE., Szulc K., Bajda Z.: Native breeds of pigs - state of breeding and results of evaluation for 2018. National Research Institute of Animal Production, Krakow 2019

47. Tarladgis B. G., Watts B. M., Younathan M. T., Dugan L.: A distillation method for the quantitative determination of malonaldehyde in rancid foods. J. Am. Oil Chem. Soc. 1960, 37, 44-48.

48. Teets A. S., Were L. M.: Inhibition of lipid oxidation in refrigerated and frozen salted raw minced chicken breasts with electron beam irradiated almond skin powder. Meat Sci. 2008, 80, 1326-1332.

49. Tikk K., Lindahl G., Karlsson A. H., Andersen H. J.: The significance of diet, slaughter weight and aging time on pork colour and colour stability. Meat Sci. 2008, 79, 806-816

50. Vieira C., García-Cachán M. D., Recio M. D., Domínguez M., Sañudo C.: Effect of ageing time on beef quality of rustic type and rustic $\times$ Charolais crossbreed cattle slaughtered at the same finishing grade. Span. J. Agric. Res. 2006, 4, 225-234.

51. Witte V. C., Krause G. F., Bailey M. E.: A new extraction method for determining 2-thiobarbituric acid values of pork and beef during storage. J. Food Sci. 1970, $35,582-585$

52. Wojtysiak D., Poltowicz K.: Carcass quality, physico-chemical parameters, muscle fibre traits and myosin heavy chain composition of $\mathrm{m}$. longissimus lumborum from Puławska and Polish Large White pigs. Meat Sci. 2014, 97, 395-403.

53. Wojtysiak D., Poltowicz K.: Effect of Ageing Time on Microstructure, Rate of Desmin Degradation and Meat Quality of Pig Longissimus Lumborum and Adductor Muscles. Folia Biol. (Kraków) 2015, 63, 151-158.

54. Wood J. D., Brown S. N., Nute G. R., Whittington F. M., Perry A. M., Johnson $S$. $P$., Enser $M$.: Effects of breed, feed level and conditioning time on the tenderness of pork. Meat Sci.1996, 44, 105-112.

55. Wood J. D., Wiseman J., Cole D. J. A.: Control and manipulation of meat quality, [in:] Cole D. J. A., Wiseman J., Varley M. A. (eds.): Principles of Pig Science. Nottingham University Press, Sheffield 1994, p. 433-456.

Corresponding author: prof. dr hab. ing. Mariusz Florek, ul. Akademicka 13, 20-950 Lublin, Poland; e-mail: mariusz.florek@up.lublin.pl 